\title{
High-Temperature Corrosion of APS- and HVOF-Coated Nickel-Based Super Alloy under Air Oxidation and Melted Salt Domains
}

\author{
Ibrahim A. Alnaser ${ }^{1}\left(\mathbb{D}\right.$, Mohammed Yunus $^{2, *}$, Rami Alfattani $^{2}{ }^{\circledR}$ and Turki Alamro ${ }^{2}$ \\ 1 Mechanical Engineering Department, King Saud University, Riyadh 11421, Saudi Arabia; ianaser@ksu.edu.sa \\ 2 Department of Mechanical Engineering, Umm Al-Qura University, Makkah City 24372, Saudi Arabia; \\ rafattni@uqu.edu.sa (R.A.); tsamro@uqu.edu.sa (T.A.) \\ * Correspondence: myhasan@uqu.edu.sa
}

\section{check for} updates

Citation: Alnaser, I.A.; Yunus, M.; Alfattani, R.; Alamro, T.

High-Temperature Corrosion of APSand HVOF-Coated Nickel-Based Super Alloy under Air Oxidation and Melted Salt Domains. Materials 2021, 14, 5119 https://doi.org/10.3390/ ma14185119

\section{Academic Editors:}

Mohammadreza Daroonparvar and Raman Singh

Received: 10 June 2021

Accepted: 24 August 2021

Published: 7 September 2021

Publisher's Note: MDPI stays neutral with regard to jurisdictional claims in published maps and institutional affiliations.

Copyright: (c) 2021 by the authors. Licensee MDPI, Basel, Switzerland. This article is an open access article distributed under the terms and conditions of the Creative Commons Attribution (CC BY) license (https:/ / creativecommons.org/licenses/by/ $4.0 /)$.

\begin{abstract}
Various thermal spraying approaches, such as air/atmospheric plasma spraying (APS) and high-velocity oxy-fuel (HVOF) spraying, are widely employed by plants owing to their flexibility, low costs and the high surface quality of the manufactured product. This study focuses on the corrosion behavior of a Ni superalloy coated with powder $\mathrm{Cr}_{3} \mathrm{C}_{2}-25 \mathrm{NiCr}$ through APS and $\mathrm{HVOF}$ at $950{ }^{\circ} \mathrm{C}$ under air oxidation and $\mathrm{Na}_{2} \mathrm{SO}_{4}+0.6 \mathrm{~V}_{2} \mathrm{O}_{5}$ molten salt environments (MSE). The results show that HVOF-deposited Ni superalloys have higher hardness and bond strength than the respective APS coating. The thermo-gravimetric probe reveals that the Ni superalloys exposed to an oxidizing air environment has a minor mass gain compared to those under the MSE domain for both non-coated and coated samples, in line with the parabola curvature rate oxidizing law. The Ni superalloys show good corrosion resistance but poor oxidation resistance in APS-deposited Ni superalloys under the MSE. HVOF-coated Ni superalloys in both environments exhibit better corrosion resistance and lower mass gain than APS-coated superalloys. The excellent coating characteristics of HVOF-coated Ni superalloys lead to their better high-temperature corrosion performance than APS.
\end{abstract}

Keywords: alloy 80A; high-velocity oxy-fuel; atmospheric plasma spraying; hot corrosion resistance; molten salt environment; air oxidation

\section{Introduction}

Presently, for running power plants (PP), it is mandatory to follow strict emission conditions to ensure environmental safety. Harmful emissions such as acid rain, severe air pollution and global warming can be reduced in power plants by using advanced ultrasupercritical technology (AUST). AUST generates more power and less volume of effluent emissions $\left(\mathrm{CO}_{2}, \mathrm{NO}_{\mathrm{x}}\right.$ and $\left.\mathrm{SO}_{2}\right)$ for the same fuel consumption and capital investment when compared to subcritical (conventional) PPs. The conventional plant efficiency is $0.85 \%$ more than AUST. The AUST-PP needs higher operating values, such as 365 bar and $720^{\circ} \mathrm{C}$, than supercritical PPs, with inlet conditions of 240 bar and $565^{\circ} \mathrm{C}$ [1]. The superalloy materials as structural elements of these PPs need to withstand hot corrosion (HC) at high operating conditions. HC involves high-temperature (HT) oxidation, which decomposes materials (metals and alloys) in the presence of salt or molten salt deposited on its surface. Molten salt will degrade materials faster than the air/gaseous oxidation conditions. The increased porosity and developed destructive oxide scale on the surface and sulfides in the substrate are an indication of HC attack occurring at HTs [2]. The HC problem has been identified in boilers, industry waste fireboxes and incineration engines. Kamal et al. [3] explained the $\mathrm{HC}$ phenomenon as dispersion of the defensive oxide deposit by reaction of fused salt $\left(\mathrm{Na}_{2} \mathrm{O}\right)$. As the gas turbine (GT) working temperatures are very high, it is necessary to obtain newer materials and plan improvements to take into account the higher efficiency and power production compared to conventional GTs. Meanwhile, the higher intake gas 
temperature in GT systems makes them more prone to HC, especially in the presence of contaminants such as $\mathrm{Na}, \mathrm{V}$ and $\mathrm{S}$ in fuel-mode salt residues on the constituent surface [4]. The HC phenomenon in boilers remains analogous to GTs [5]. The use of magnesium and magnesium-based inhibitors can prevent $\mathrm{HC}$ to a certain degree [6] and widespread probes revealed that $\mathrm{Mg}, \mathrm{Mn}$ and Ca-based inhibitors can effectively reduce $\mathrm{HC}$ in a $\mathrm{Na}_{2} \mathrm{SO}_{4}+0.6 \mathrm{~V}_{2} \mathrm{O}_{5}$ environment at $900{ }^{\circ} \mathrm{C}$, but their use is hindered because of practical difficulties in feeding the inhibitors into the fuel [7].

Most advanced nickel $(\mathrm{Ni})$ superalloys contain $\mathrm{Cr}$ and $\mathrm{Al}$ content in an adequate quantity to cause the particular oxidation of these elements, which are promising GT materials. Ni superalloys produce either alumina or chromia. Ni superalloys with high $\mathrm{Cr}$ are suitable for environments with sulfur and carbon. Alloy 80A (UNS NO7080 (ASTM B637-06)) is a Ni superalloy fabricated for $\mathrm{HT}$ applications at $815^{\circ} \mathrm{C}$, primarily composed of $\mathrm{Ni}$ and $\mathrm{Cr}$ and strengthened by $\mathrm{Ti}, \mathrm{Al}$ and $\mathrm{C}$ addition. Alloy $80 \mathrm{~A}$ is mostly employed in the components (blades, combustion liners, transition pieces, seal rings, joining bolts and discs) of GTs and steam turbines (ST) [1]. The efficiency of STs and the lifetime of their parts can be improved by the selection of an appropriate material and production technique.

However, further research work is needed to ensure the reliable corrosion behavior of the different materials and coating powders in various environments. It is necessary to take into account the inherent characteristics of thermal spray coatings (TSC) [8]. Hightemperature corrosion is inevitable in the presence of an aggressive environment, particularly in fabricated parts exposed for long durations to high-temperature environments [9]. There are two different methods used to protect the long-lived components and enhance the corrosion resistance: the addition of $\mathrm{Al}, \mathrm{Cr}$ and Ti with a small $\%$ of $\mathrm{Y}, \mathrm{Zr}$ and $\mathrm{H}_{\mathrm{f}}$ to the base alloy [10] and surface modification technologies for depositing protective coatings. These techniques include diffusion coating, TSC, chemical and physical vapor deposition (CVD and PVD), weld overlay, etc. [11]. Many considerable efforts have been devoted to investigating the properties of components with and without coatings when exposed to different environments. However, our understanding the corrosive/protective mechanisms of different substrates/coatings is limited and they need further study. When thick coatings were applied to boiler and turbine components, their lifetimes were enhanced under severe working conditions [12]. The initiation of hot corrosion requires a longer time than its propagation.

The significant benefits of TSC are high production rates for coating thicknesses above $100 \mu \mathrm{m}$, applicable for a wide range of substrate (metal and non-metal) and coating powders (ceramic and carbide) $[13,14]$. However, additional research work is needed to ensure the reliable corrosion behavior of the multiple materials with different coating powders in various environments. The oxidation resistance (OR) of nickel superalloy at 950 and $1000{ }^{\circ} \mathrm{C}$ for $140 \mathrm{~h}$ in an air environment and the oxidation behavior of the alloy followed the parabola curvature rate oxidizing law at $950{ }^{\circ} \mathrm{C}$ and slightly deviated from it at $1000{ }^{\circ} \mathrm{C}$ [15]. There is no scale spallation from the alloy at $950{ }^{\circ} \mathrm{C}$ but minor spallation of scales was noted at $1000^{\circ} \mathrm{C}$ [16]. There are two types of $\mathrm{HC}$ processes: type I is high-temperature $\mathrm{HC}$ from 850 to $950{ }^{\circ} \mathrm{C}$ caused by $\mathrm{Na}_{2} \mathrm{SO}_{4}$ fused salt because of its high thermodynamic stability, and type II (low-temperature (LT)) HC at 650 to $800{ }^{\circ} \mathrm{C}$ occurs in the eutectic mixtures of fused salts. The basic fluxing is the primary $\mathrm{HC}$ mechanism occurring in alumina and chromia, forming nickel-based superalloys. The combustion of low-quality graded fuels in power generation systems leads to the occurrence of vanadium contaminants, which oxidize and form $\mathrm{V}_{2} \mathrm{O}_{4}$ and $\mathrm{V}_{2} \mathrm{O}_{5}$ [17]. High corrosion above $800{ }^{\circ} \mathrm{C}$ is found initially in all materials, but later, this corrosion becomes constant or lowers with a further increase in temperature. The formed $\mathrm{Na}_{2} \mathrm{CrO}_{4}$ is mixable in $\mathrm{Na}_{2} \mathrm{SO}_{4}$ melt. Unalloyed Ni material exhibits less $\mathrm{HC}$ resistance than $\mathrm{Ni}-\mathrm{Cr}, \mathrm{Ni}-\mathrm{V}$ and $\mathrm{Ni}-\mathrm{Mo}$ alloys in the presence of fused $\mathrm{Na}_{2} \mathrm{SO}_{4}$ salt.

Coatings applied with various deposition methods, such as wire arc, atmospheric or air plasma (APS), high-velocity oxy-fuel (HVOF), cold spraying, etc., possess different characteristics [7]. APS coating during the HT oxidation of Ni superalloys (Superni 75, 600, 
and 601) coated with $\mathrm{Ni}-20 \mathrm{Cr}$ powder at $900{ }^{\circ} \mathrm{C}$ revealed that the coating was retained without spallation for up to 50 cycles [18]. The influence of a $\mathrm{Cr}_{3} \mathrm{C}_{2}-\mathrm{NiCr}$ coating using APS during the HT oxidation of $2.25 \mathrm{Cr}-1 \mathrm{Mo}$ steel in a constant-temperature trial at $700{ }^{\circ} \mathrm{C}$ for three days and weight loss were assessed at several time points. The results showed an enhancement in the OR of 2.25Cr-1Mo steel as the actual OR improved in the $\mathrm{Cr}_{2} \mathrm{O}_{3}$ layer formed by the $\mathrm{C}_{\mathrm{r} 3} \mathrm{C}_{2} \mathrm{NiCr}$ (chromium carbide-nickel chromium) coating $[19,20]$. The corrosion diffusion mechanism in an APS-sprayed $\mathrm{Cr}_{3} \mathrm{C}_{2}-\mathrm{NiCr}$ coating through the inward diffusion of oxygen anions from the oxidation environment to coating layers was evaluated. In the non-coated base metal, the outward migration of iron cations from the substrate surface occurred. Two different diffusion mechanisms of corrosion improved the OR to a significant range. The HVOF process uses gases such as hydrogen, acetylene and propylene and liquid fuels such as kerosene to melt the high powder particle velocities from 480 to $840 \mathrm{~m} / \mathrm{s}$ and deposit them onto base metals. During the HC evaluation of a T-91 alloy steel boiler tube and HVOF deposited with $\mathrm{Cr}_{3} \mathrm{C}_{2}+0.25 \mathrm{Ni} 20 \mathrm{Cr}$ under 540,700 and $850^{\circ} \mathrm{C}$ temperatures, the coating showed the most negligible weight gain compared to uncoated specimens as deposition reduced the corrosion frequency significantly [21]. HC deportment of base metals (SA213-T22, MDN310 and Superfer800H) and HVOF deposited with $\mathrm{Cr}_{3} \mathrm{C}_{2}$ $0.35 \mathrm{NiCr}+0.05 \mathrm{Si}$ powder under $\left(\mathrm{Na}_{2} \mathrm{SO}_{4}+0.60 \mathrm{~V}_{2} \mathrm{O}_{5}\right)$ at $700{ }^{\circ} \mathrm{C}$ showed a laminar structure with low porosity $[22,23]$. Steel base metals exhibited a better OR than uncoated steel. Both coated and uncoated steel followed the parabola curvature rate oxidizing law, and the parabolic rate constant of coated steel was lower than that of uncoated steel [24]. $\mathrm{Cr}_{2} \mathrm{O}_{3}$ and $\mathrm{SiO}_{2}$ oxides developed over the exterior layer were inactive in the melted $\mathrm{NaVO}_{3}$ salt.

A limited number of studies are available on the HT corrosion behavior of Ni superalloy exposed to air oxidation/corrosion (AC) and a melted salt environment (MSE) at $950^{\circ} \mathrm{C}$. As the temperature is quite high, an effective method required to extend this study is to apply a protective coating that resists the corrosion of the exposed surfaces. Such deposits have been found to improve the longevity of the base material/alloy to a certain level [25-28]. Numerous TSC methods, such as APS and HVOF, are extensively utilized to deposit high $\mathrm{Ni}$ and $\mathrm{Cr}$ powder coatings onto various $\mathrm{PP}$ component surfaces in order to withstand $\mathrm{HC}[4,29]$. The present work utilizes $\mathrm{Cr}_{3} \mathrm{C}_{2}-25 \mathrm{NiCr}$ powder, which was chosen as the high chromium $(\mathrm{Cr})$ content of the material is advantageous for providing $\mathrm{HC}$ resistance by protecting the oxidic layers of $\mathrm{Cr}_{2} \mathrm{O}_{3}$ on the Ni superalloy's surface. Thermally sprayed $\mathrm{Cr}_{3} \mathrm{C}_{2}-25 \mathrm{NiCr}$ depositions are extensively employed in several areas to protect the exposed surfaces and resist wear and HT corrosion under harsh conditions [30]. The coatings contribute exceptional tribological attributes at raised temperatures, improve the components lifetimes at such HT conditions in the PP system, and sustain high wearing resistance up to $880^{\circ} \mathrm{C}$ in turbine and boiler components [31]. Ni-Cr-based metal coatings can develop remarkable $\mathrm{HC}$ resistance in $\mathrm{AC}$. However, there are two different oxidation conditions (such as AC and MSE) for two different TSC methods. Hence, $\mathrm{Na}_{2} \mathrm{SO}_{4}+0.6 \mathrm{~V}_{2} \mathrm{O}_{5}$ salt is chosen for the MSE, employing thermocycling terms associated with real-time automated background climate specifications, where the production plant disorder occurs frequently.

From the above explorations, it can be inferred that earlier researchers have not concentrated on the mechanical characteristics and oxidation resistance of $\mathrm{Cr}_{3} \mathrm{C}_{2}-25 \mathrm{NiCr}$ depositions at high temperatures by means of modern TSCs under air and melted salt. The present work examines the HVOF and APS coating characteristics, such as hardness and bond strength, for $\mathrm{Cr}_{3} \mathrm{C}_{2}-25 \mathrm{NiCr}$ powder and the $\mathrm{HC}$ behavior of uncoated alloy $80 \mathrm{~A}$ in $\mathrm{AC}$ and MSE. Moreover, we investigate the HC characteristics of the deposited Ni superalloy's surface by means of APS and HVOF spray processes when exposed to $950^{\circ} \mathrm{C}$ for 50 cycles.

\section{Experimental Procedure}

The experimental procedure adopted to deposit the coatings via the APS and HVOF methods using $\mathrm{Cr} 3 \mathrm{C} 2-25 \mathrm{NiCr}$ powder to determine the $\mathrm{HC}$ resistance at $950{ }^{\circ} \mathrm{C}$ under $\mathrm{AO}$ and MSE is illustrated in detail. The procedure to characterize the coatings includes measurement of the hardness, bond strength and $\mathrm{HC}$ resistance during both processes, as 
explained in detail. The base metal material, Ni superalloy (commercial name: alloy 80A), is utilized for this current research. The chemical composition of the Ni superalloy as the as-received base metal is detailed in Table 1 . The Ni superalloy selected had the shape of a 64-mm-diameter cylindrical rod, sliced into $64 \mathrm{~mm} \times 7 \mathrm{~mm}$ thick discs and sliced into rectangular pieces of $20 \mathrm{~mm} \times 15 \mathrm{~mm} \times 7 \mathrm{~mm}$ by employing the Electrical Discharging Machining (EDM) process. The coating was applied on the base metal alloy 80A using APS and HVOF methods in the present study. Before coating, the base metals were initially grit-blasted with white alumina $\left(\mathrm{Al}_{2} \mathrm{O}_{3}\right)$ at 4 bar blasting pressure and then glazed utilizing fine-sized grit silicon carbide ( $\mathrm{SiC})$ paper [32].

Table 1. Chemical arrangement (in percent weight) of alloy $80 \mathrm{~A}$ base metal and coating powders.

\begin{tabular}{|c|c|c|c|c|c|c|c|c|c|c|c|}
\hline \multirow{2}{*}{ Base Metal and Coating Powder } & \multicolumn{11}{|c|}{ Chemical Composition (Wt \%) } \\
\hline & $\mathrm{Ni}$ & $\mathrm{Cr}$ & $\mathrm{C}$ & $\mathrm{Fe}$ & Mo & Co & $\mathrm{Nb}$ & Al & $\mathrm{Ti}$ & Mn & Si \\
\hline Alloy $80 \mathrm{~A}$ base metal & Bal. & 19.33 & 0.074 & 0.3 & - & 0.2 & Nil & 1.43 & 2.38 & 0.6 & 0.1 \\
\hline $\mathrm{Cr}_{3} \mathrm{C}_{2}-25 \mathrm{NiCr}$ & 20.60 & Bal. & 9.6 & 0.15 & - & - & - & - & - & - & - \\
\hline
\end{tabular}

The two coating methods (refer to Figures 1 and 2) were used to deposit the coatings onto to all the surfaces of the Ni superalloy utilizing APS (thickness of $150 \mu \mathrm{m}$ ) and HVOF $(200 \pm 5 \mu \mathrm{m})$ processes; the employed process parameters are listed in Table 2 . For the APS method, we deposited the coating via a 3MB plasma air gun (Sulzer Metco made), with $100 \mathrm{~kW}$ power input, and we used argon (Ar) and hydrogen $\left(\mathrm{H}_{2}\right)$ as input gases. The HVOF coating was performed using a multiple coating system operated with oxygen and jet fuel [33].

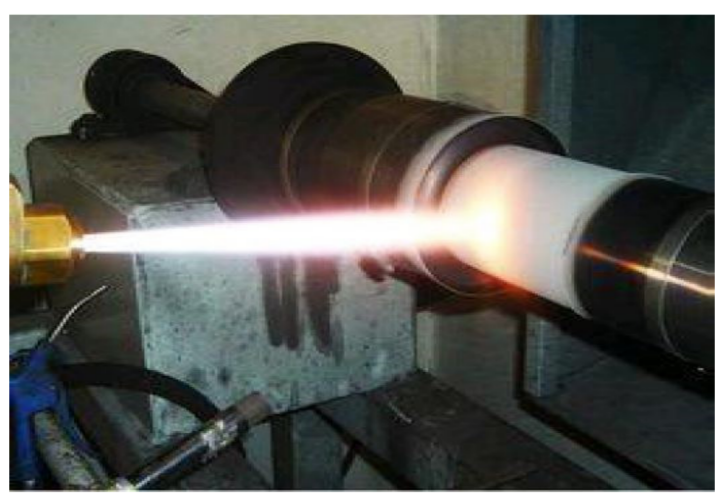

Figure 1. Photograph of plasma spray system.

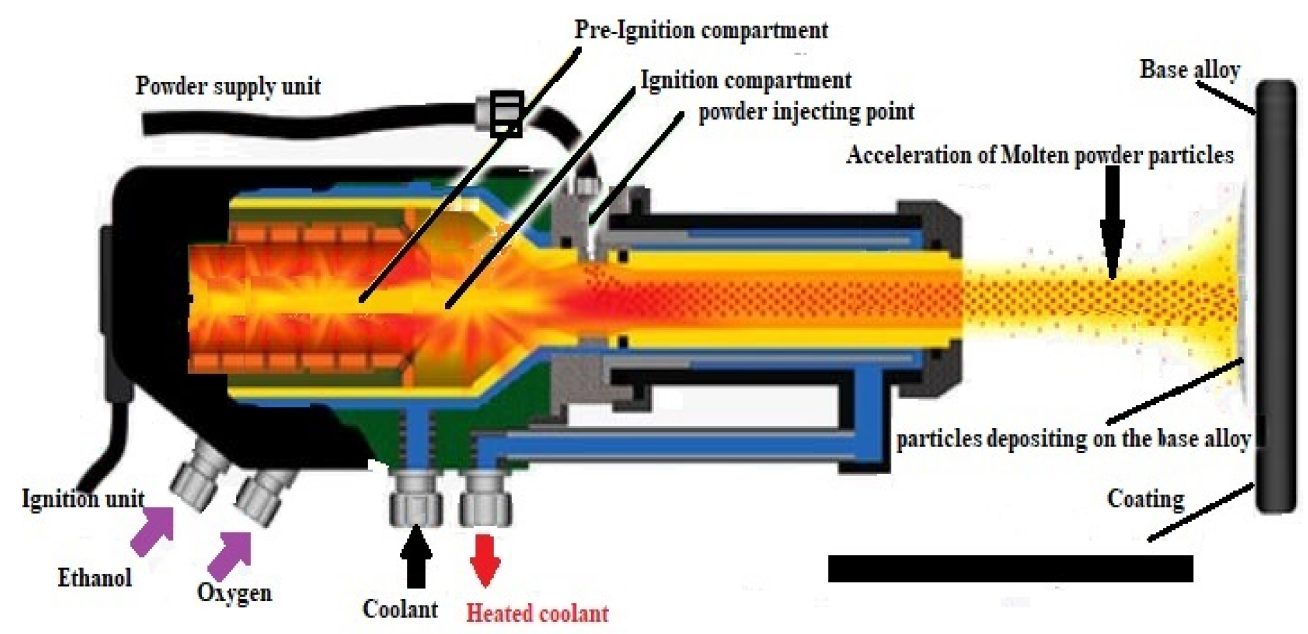

Figure 2. Schematic layout of HVOF spray system. 
Table 2. Control parameters of APS and HVOF spray coating technique for $\mathrm{Cr}_{3} \mathrm{C}_{2}-25 \mathrm{NiCr}$ powder.

\begin{tabular}{ccc}
\hline Process Parameter & APS & HVOF \\
\hline Argon (Ar) flow rate $(\mathrm{lpm})$ & 55 & - \\
Hydrogen $\left(\mathrm{H}_{2}\right.$ ) flow rate $(\mathrm{lpm})$ & 12 & - \\
Argon carrier flow rate $(\mathrm{lpm})$ & 3.2 & 840 \\
$\mathrm{O}_{2}$ flow rate $(\mathrm{lpm})$ & - & 20 \\
Jet fuel flow rate $(\mathrm{lpm})$ & - & - \\
$\mathrm{Ar}, \mathrm{H}_{2}$ and Ar carrier pressure $(\mathrm{MPa})$ & $0.5,0.5 \& 0.5$ & $1,0.7 \& 0.25$ \\
$\mathrm{O}_{2}$, fuel and Ar carrier pressure $(\mathrm{MPa})$ & - & 0.58 \\
Powder inputting rate $(\mathrm{gm} / \mathrm{s})$ & 0.66 & - \\
Current (Amps) & 600 & - \\
Voltage (Volts) & 80 & $90^{\circ}$ \\
Deposition angle & $90^{\circ}$ & 365 \\
Stand-off distance $(\mathrm{mm})$ & 130 &
\end{tabular}

\subsection{Characterization of Coatings}

Various important characteristics of the coated substrates were evaluated, including micro-hardness, bond strength and $\mathrm{HC}$ resistance.

\subsubsection{Bond Strength Testing}

The tensile-based adhesive/bond strength of the coating was evaluated independently utilizing a novel kind of specimen holder on a developed cylindrical-shaped dummy-coated specimen with a diameter of $25.4 \mathrm{~mm} \times$ length $38.1 \mathrm{~mm}$.

All dummy surfaces were roughened. Every roughened dummy face was fixed on top of a substrate sample using 'epoxy 900-C' (polymeric adhesive) and subjected to tension after being mounted on the jig. Specimens were placed in a universal testing machine and pulled with a crosshead speed of $0.02 \mathrm{~mm} / \mathrm{s}$ until the two parts separated. The bond strength of the coatings was estimated considering ASTM C633 standards. When pulled in a plane, or once rupture occurred, the maximum load was recorded. Bond strength is the ratio of the maximum load to the cross-section area of the samples. After thermal curing with epoxy glue, the deposited and undeposited samples were placed between pairing cylinders of $50 \mathrm{KN}$ capacity. The schematic diagram for the bond strength testing is shown in Figure 3. The average value was estimated, excluding the maximum and minimum value, in each set of five readings to eliminate any possible distortion of the results owing to any outliers. This approach was taken with all tests.

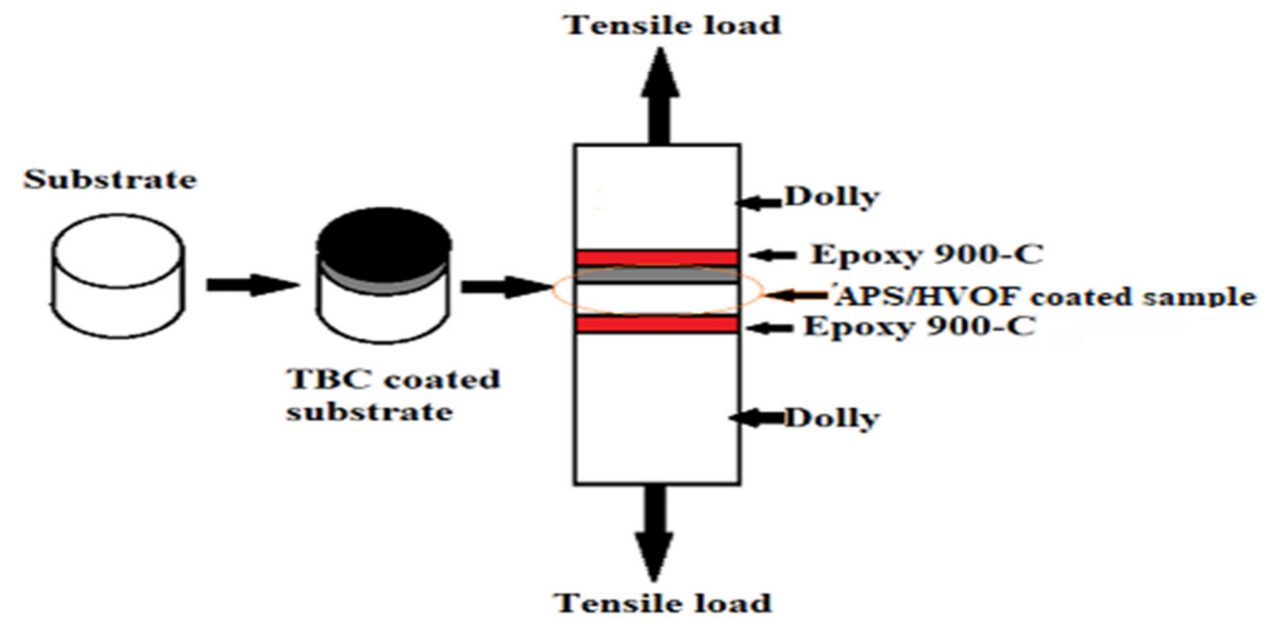

Figure 3. Schematic layout of bond strength test (ASTM C633) [34]. 


\subsubsection{Pictorial Examination}

After each cycle, every sample was examined visually for any change in color, crack formation and changes in surface properties. After the completion of 50 cycles, each specimen was examined, and their macrographs were prepared. The physical visual examination (spallation and formation of cracks) on the surface of sample was performed using the macrographs.

\subsubsection{Mass Gain Analysis}

The kinetics of hot corrosion were determined by the measurement of the mass change values of each sample after each cycle. Then, the graph was plotted between the mass change data and number of cycles.

\subsubsection{Cyclic High-Temperature Corrosion Test}

A trial of HT corrosion was performed for up to fifty cycles on the undeposited and APS- and HVOF-deposited Ni superalloys under both AO and MSE $\left(\mathrm{Na}_{2} \mathrm{SO}_{4}+0.6 \mathrm{~V}_{2} \mathrm{O}_{5}\right)$ environments. Specimens were heated in a tubular furnace at $905^{\circ} \mathrm{C}$ for around $60 \mathrm{~min}$ and then cooled for 20 min to reach an ambient temperature-this was considered one cycle. First, a non-deposited base metal, as well as the APS- and HVOF-deposited samples, were heated at $200{ }^{\circ} \mathrm{C}$ in the furnace (refer to Figure 4) before being exposed to MSE to apply the $\mathrm{Na}_{2} \mathrm{SO}_{4}+0.6 \mathrm{~V}_{2} \mathrm{O}_{5}$ salt. Purified water with a salt mixture of $\mathrm{Na}_{2} \mathrm{SO}_{4}+0.6 \mathrm{~V}_{2} \mathrm{O}_{5}$, called molten salt, was applied at a uniform rate of $3.0-5.0 \mathrm{mg} / \mathrm{cm}^{2}$ on the base metal's surface using the brush. Then, they were kept at $150{ }^{\circ} \mathrm{C}$ in the box furnace for $4 \mathrm{~h}$ to ensure proper adhesion of salt by removing the moisture [35]. The mass change in the Ni superalloy with alumina boat $(\mathrm{AB})$ was measured for every cycle during the $\mathrm{HC}$ test together with fragments of deposited oxide scale in the $\mathrm{AB}$. Tests were repeated five times to maintain accuracy and repeatability of measurements.

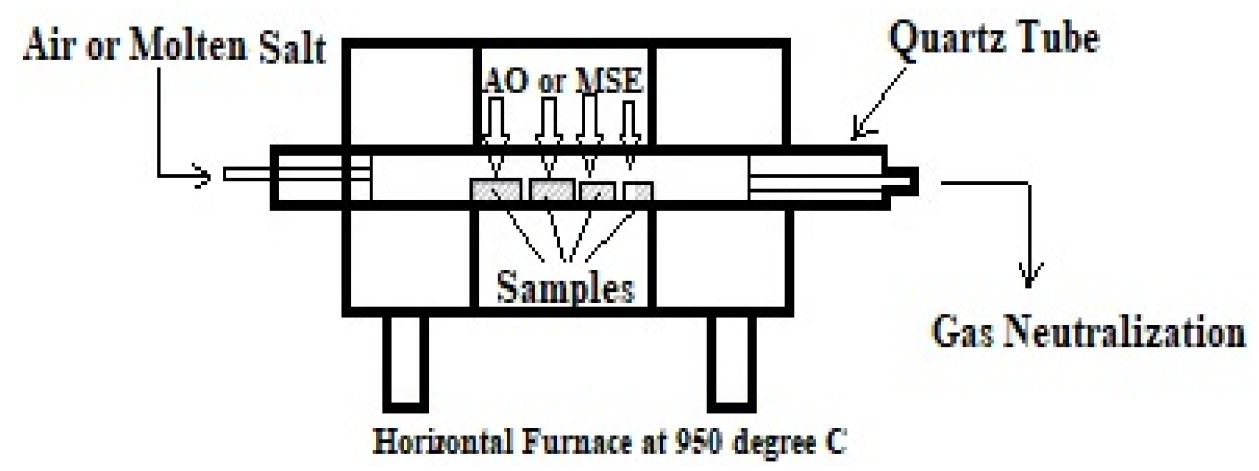

Figure 4. Schematic layout of HC test on samples in the tubular furnace subjected to the AO and MSE environments.

\subsubsection{Micro-Hardness Testing}

Micro-hardness testing was conducted on cross-sections of the deposited base metals and it was measured from the base metal's surface and the top surface of the deposition by taking nine indentations randomly, adopting ASTM E384 procedures [36].

\section{Results and Discussion of Air Plasma Spray Coating}

$\mathrm{Ni}$ superalloys were deposited with the APS and HVOF systems employing $\mathrm{Cr}_{3} \mathrm{C}_{2}-25 \mathrm{NiCr}$ powder. Various coating parameters, such as micro-hardness and bond strength, were measured, and thermogravimetric analysis was performed, for every cycle for up to fifty cycles. Results were plotted to estimate the mass gain of the undeposited and deposited samples under AO and MSE oxidation environments. 


\subsection{Microhardness $\left(H_{v}\right)$ of the Base Metal and Depositions (APS and HVOF)}

Figure 5 illustrates the micro-hardness profile across the alloy $80 \mathrm{~A}$ and $\mathrm{Cr}_{3} \mathrm{C}_{2}-25 \mathrm{NiCr}$ powder-deposited base metals using the APS and HVOF processes. The $\mathrm{H}_{\mathrm{V}}$ was measured using a Vickers indenter on the polished coating section under a load of $300 \mathrm{~g}$ with a dwell time of $10 \mathrm{~s}$ for every hardness test. The average of nine readings on each sample was taken as a data point. The average micro-hardness observed on the undeposited base metal alloy $80 \mathrm{~A}$ was $298 \mathrm{Hv}_{0.3}$, and that of the deposited base metals was $840 \mathrm{Hv}_{0.3}$ (APS-coated) and $862 \mathrm{H}_{\mathrm{V} 0.3}$ (HVOF-coated). The hardness values increased by $172 \%$ and $178 \%$ for the APSand HVOF-deposited base metals compared to the base alloy $80 \mathrm{~A}$. The enhanced hardness in the $\mathrm{Cr}_{3} \mathrm{C}_{2}-25 \mathrm{NiCr}$ powder was due to the presence of the $\mathrm{Cr}_{3} \mathrm{C}_{2}$ hard phase in the $\mathrm{NiCr}$ matrix and the high kinetic energy generated by the powder particles [37].

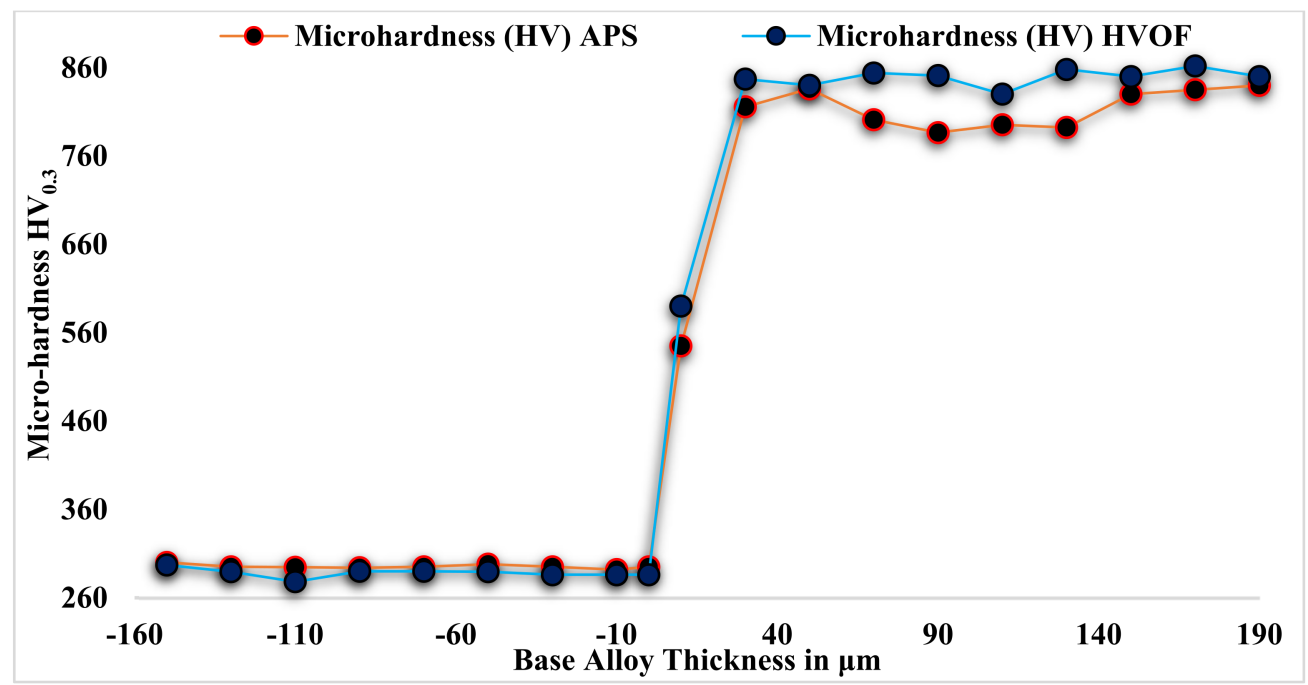

Figure 5. Microhardness of $\mathrm{Cr}_{3} \mathrm{C}_{2}-25 \mathrm{NiCr}$ powder-coated (APS and HVOF) and uncoated base alloy.

\subsection{Adhesion/Bond Strength of the Deposits}

The bond/adhesion strength was noted as 41 and $72 \mathrm{MPa}$ in the APS- and HVOFdeposited NI superalloys; it was between $34 \mathrm{MPa}$ and $68 \mathrm{MPa}$ according to the ASTM C633 standard [38], and the type of deposit failure was cohesion [39]. On the other hand, in HVOF depositions, glue-type failure occurred and the result was greater than the glue strength employed in the test.

\subsection{Pictorial Examination}

Figure $6 a-f$ depict the macrographs of undeposited (refer to Figure $6 a, b)$, APS- (refer to Figure $6 \mathrm{c}, \mathrm{d}$ ) and HVOF-deposited base alloy $80 \mathrm{~A}$ (refer to Figure $6 \mathrm{e}, \mathrm{f}$ ) up to the 50th cycle under the $\mathrm{AO}$ and MSE environments $\left(\mathrm{Na}_{2} \mathrm{SO}_{4}+0.6 \mathrm{~V}_{2} \mathrm{O}_{5}\right)$ at $950{ }^{\circ} \mathrm{C}$. In the first few cycles (first to fifth), the color of the undeposited and APS-deposited Ni Superalloy in both environments changed to light and dark grey colors. These colors started to change to a brown color after the 20th cycle, and the same occurred up to the fiftieth cycle. Random scale accumulation was witnessed during the third cycle onwards in the MSE domain on both the undeposited and APS-deposited Ni superalloy. The severe ejection of fragments of coated powder/spallation at edges was observed in the APS-deposited Ni superalloy under the AO domain, but very minimal deposited layer spallation at the top was observed from the fifth cycle to the fifteenth cycle; after this, no spallation occurred in subsequent cycles. We observed the formation of bright spots on all the Ni superalloys after completion of the seventh cycle, and these continued to gradually increase in size and quantity in subsequent cycles up to the fiftieth cycle. Moreover, the corroded stock started paring off from the eighth cycle onwards, only under the MSE domain, in both the undeposited and deposited Ni superalloys [40]. 


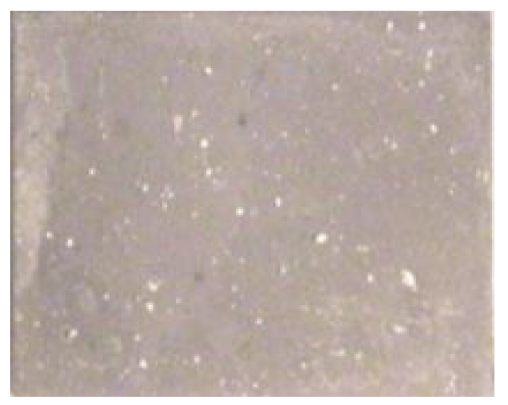

(a)

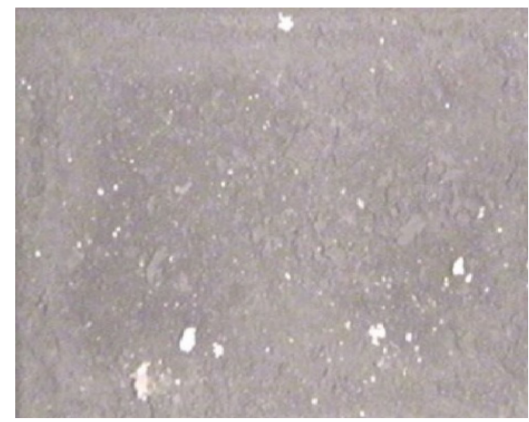

(d)

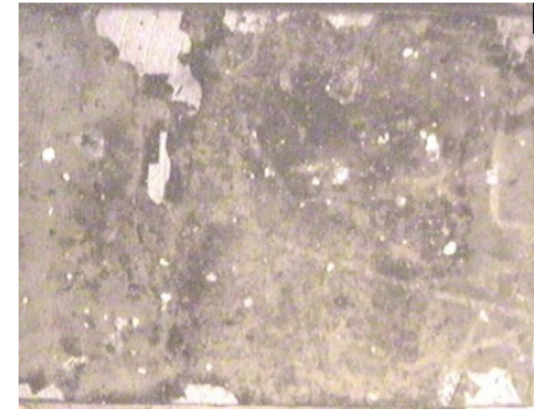

(b)

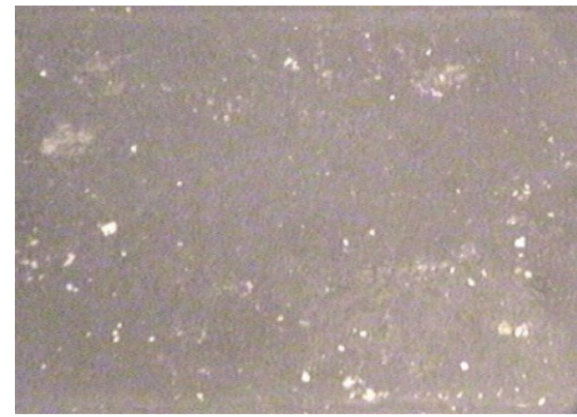

(e)

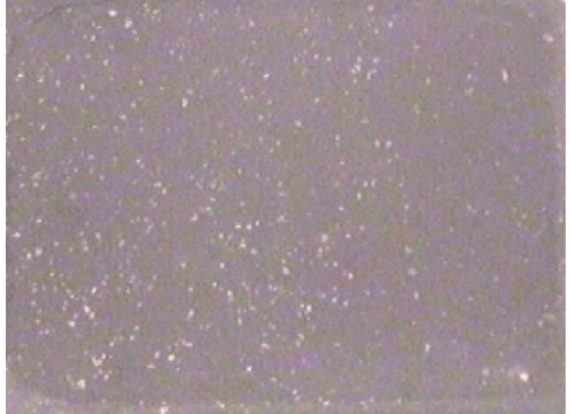

(c)

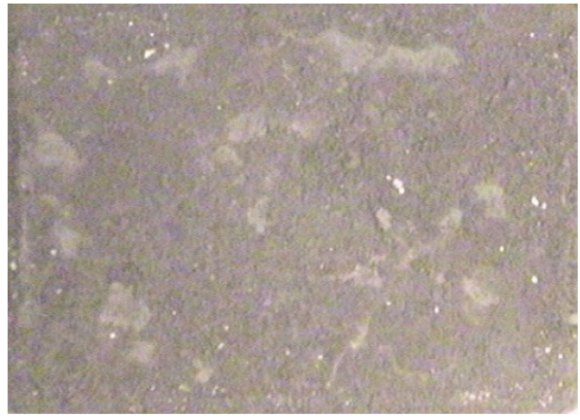

(f)

Figure 6. (a) Base metal under AO; (b) Base metal under MSE; (c) APS-coated sample under AO; (d) APS-coated sample under MSE; (e) HVOF-coated sample under AO; (f) HVOF-coated sample under MSE.

The dark grey color of the HVOF-deposited Ni superalloys under the AO domain (Figure 6e) changed into a grey color during the eighth cycle, and then no color change was found till the last cycle. During the seventh cycle, the generation of white dots was perceived on the deposited Ni superalloys exposed to the AO domain. The deep brown shade of the deposited Ni superalloys (refer to Figure 6e) subjected to MSE changed to a grey shade during the twelfth cycle and remained the same until the fiftieth cycle. The presence of white spots started to emerge under the MSE substrate during the twelfth cycle. Crack formation and paring off of deposited layers were not seen in HVOF-deposited Ni superalloys till the last cycle. Spallation of scaling started from the beginning of the seventh cycle onwards in both the deposited and undeposited samples when exposed to the MSE domain (refer to Figure 6b,f) and proceeded till the fiftieth cycle. This showed that the scale formation occurred mainly in the MSE domain compared to Ni superalloys subjected to the AO domain (refer to Figure 6a,e).

\subsection{Oxidation Kinetics}

Referring to Figure 7, the plots of the $\mathrm{Cr}_{3} \mathrm{C}_{2} 25 \mathrm{NiCr}$-deposited base metals show greater weight gain than the undeposited alloy $80 \mathrm{~A}$ base metal when subjected to AO. In particular, the weight gain of the APS-deposited base metals in the AO domain was greater than all other cases. At every 50th cycle, the calculated total weight gain values (refer to Table 3) showed that AO in both (deposited and undeposited) base metals provided significantly less gain than under MSE domains. It was also noted that $\mathrm{Cr}_{3} \mathrm{C}_{2} 25 \mathrm{NiCr}$ powder deposited by APS on base metals led to greater weight gain in the MSE domain than in the undeposited Ni Superalloy. The MG of the APS-coated substrate in the MSE domain was higher than that of the HVOF-deposited base metals for the same corrosion domain. 


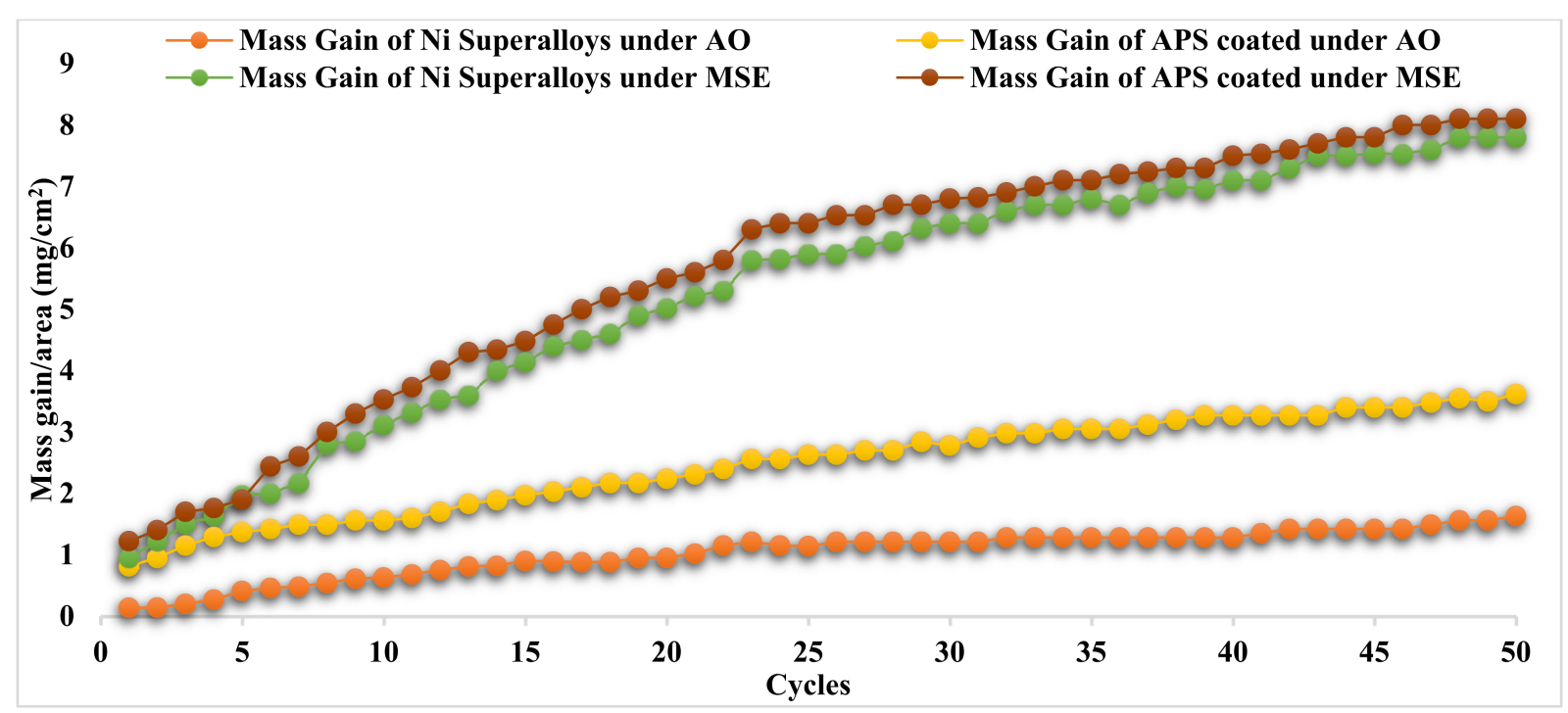

Figure 7. Mass gain vs. fifty corrosion cycles for the Ni superalloys (deposited and undeposited by APS) under both AO and MSE environments at $950^{\circ} \mathrm{C}$.

Table 3. Total MG and $\mathrm{K}_{\mathrm{P}}$ for undeposited and APS- and HVOF-deposited Ni superalloy under AO and MSE at $950^{\circ} \mathrm{C}$.

\begin{tabular}{|c|c|c|}
\hline Specimen & Whole MG $\left(\mathrm{mg} / \mathrm{cm}^{2}\right)$ & $\mathrm{K}_{\mathrm{P}}(\mathrm{MG} / \mathrm{Area})^{2} / \mathrm{Cycle}, \mathrm{g}^{2} / \mathrm{cm}^{4} / \mathrm{s}^{1}$ \\
\hline Undeposited Ni superalloy under AO & 1.46 & $1.08 \times 10^{-6}$ \\
\hline Undeposited Ni superalloy under MSE & 7.46 & $2.78 \times 10^{-5}$ \\
\hline APS-coated Ni superalloy under AO & 3.35 & $5.03 \times 10^{-6}$ \\
\hline APS-coated Ni superalloy under MSE & 7.57 & $2.62 \times 10^{-5}$ \\
\hline HVOF-coated Ni superalloy under AO & 3.09 & $4.36 \times 10^{-6}$ \\
\hline HVOF-coated Ni superalloy under MSE & 7.30 & $2.5 \times 10^{-5}$ \\
\hline
\end{tabular}

The MG graph shows that mass progressively increased with the number of cycles in the AO domain. In contrast, in the case of MSE, the mass gain was greater at the beginning of some cycles and progressively increased in additional cycles. Figure 8 for (MG/Area) ${ }^{2}$ implies that the corrosion process conforms to the parabolic law for the corrosion rate for the AO domain, and there is a deviation from this law in the case of the MSE domain for the base metals of both undeposited and APS-deposited specimens. The parabolic rates $\left(K_{P}\right)$ are listed in Table 3. As seen in Figure 8 and Table 3, $K_{P}$ values were high under the MSE domain for both undeposited and APS-deposited Ni superalloys. APS-deposited $\mathrm{Ni}$ superalloys under the $\mathrm{AO}$ domain had higher $\mathrm{K}_{\mathrm{p}}$ values than undeposited ones when exposed to the same domain. The undeposited and APS-deposited substrates in both the $\mathrm{AO}$ and MSE environments conformed to the parabolic law for the corrosion rate (refer to Figure 8$). K_{p}$ was obtained from the law, $(M G / \text { Area })^{2}=K_{P} \times x \times t$.

Regarding the undeposited Ni superalloy exposed to the AO domain, Figure 9 indicates that it experienced a weaker whole mass gain (MG) and had a lower parabola curve rate constant $\left(\mathrm{K}_{\mathrm{p}}\right)$ value than the HVOF-deposited Ni superalloy. The mass gain at the fiftieth cycle for all the base alloys is tabulated in Table 3. A greater MG was seen under the MSE domain for both Ni superalloys (undeposited and deposited) compared to the AO domain. It is also revealed in Figure 9 and Table 3 that the HVOF-deposited base alloy subjected to MSE showed a lower MG and $K_{p}$ value than the undeposited Ni superalloys. Figure 9 also illustrates that the MG quickly increased up to the eighth cycle in both Ni superalloys under both domains. After the eighth cycle, a continuous rise in MG was seen until the fiftieth cycle under both domains. The undeposited and HVOF-deposited substrates in both the AO and MSE environments conformed to the parabolic law for the corrosion rate (refer to Figure 10). $\mathrm{K}_{\mathrm{p}}$ was obtained from the law, $(\mathrm{MG} / \text { Area })^{2}=\mathrm{K}_{\mathrm{P}} \times \mathrm{x} \times \mathrm{t}$. 


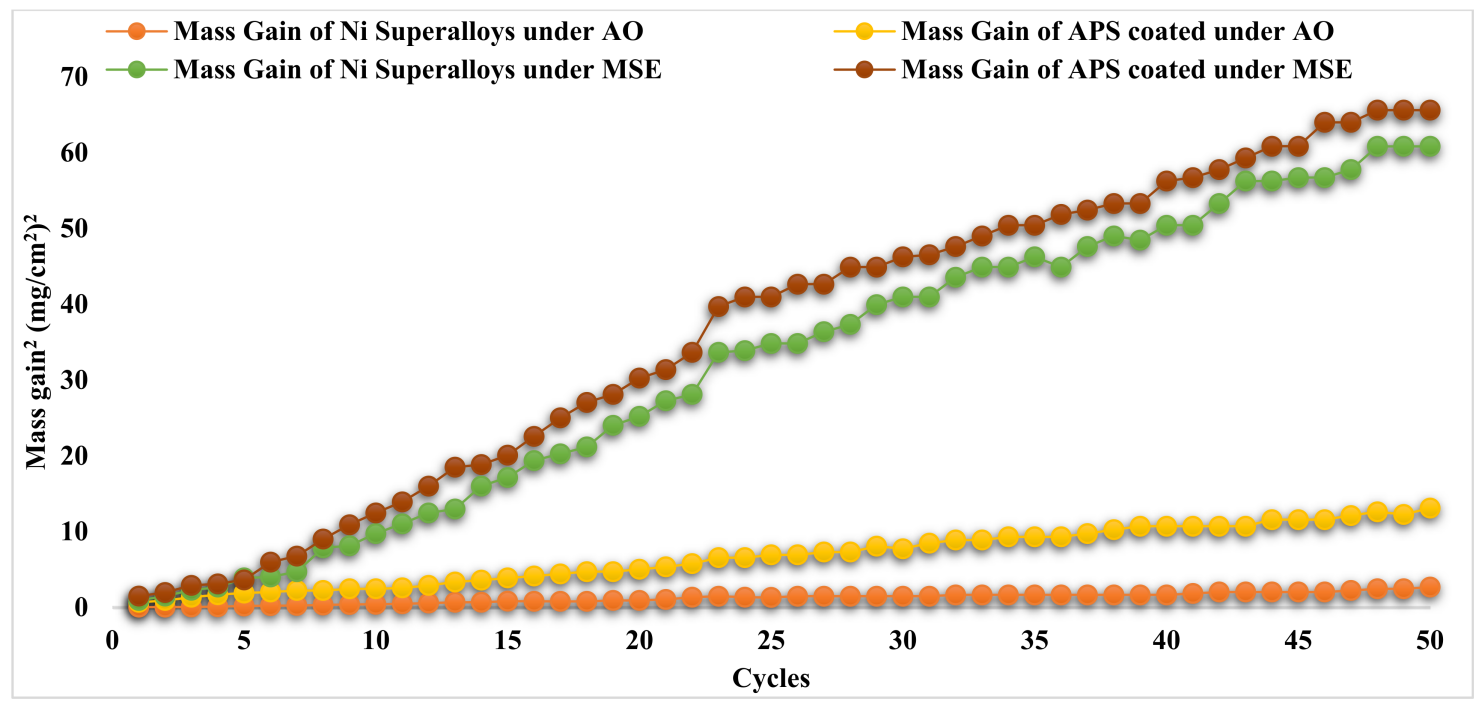

Figure 8. (Mass gain/area) ${ }^{2}$ vs. fifty corrosion cycles for Ni superalloys (undeposited and APS-deposited) under AO and MSE at $950{ }^{\circ} \mathrm{C}$.

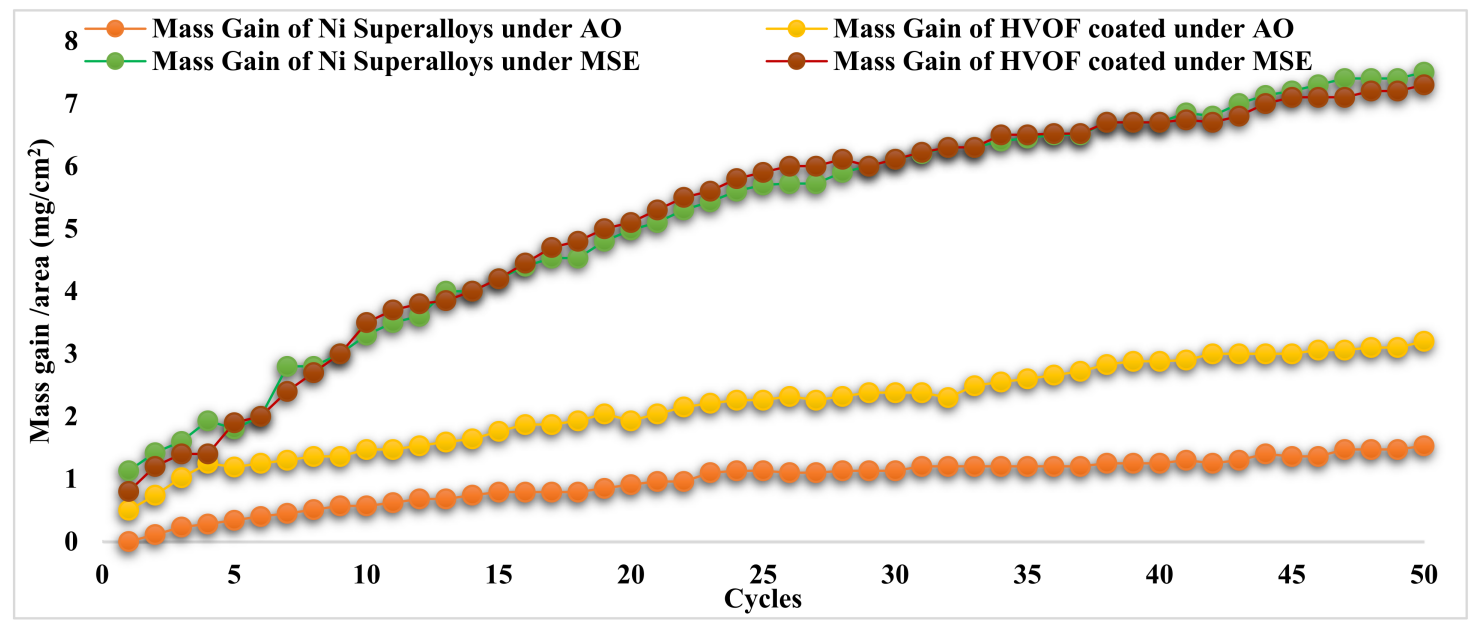

Figure 9. Mass gain vs. fifty corrosion cycles for the Ni superalloys (deposited and undeposited by HVOF) under both AO and MSE environments at $950{ }^{\circ} \mathrm{C}$.

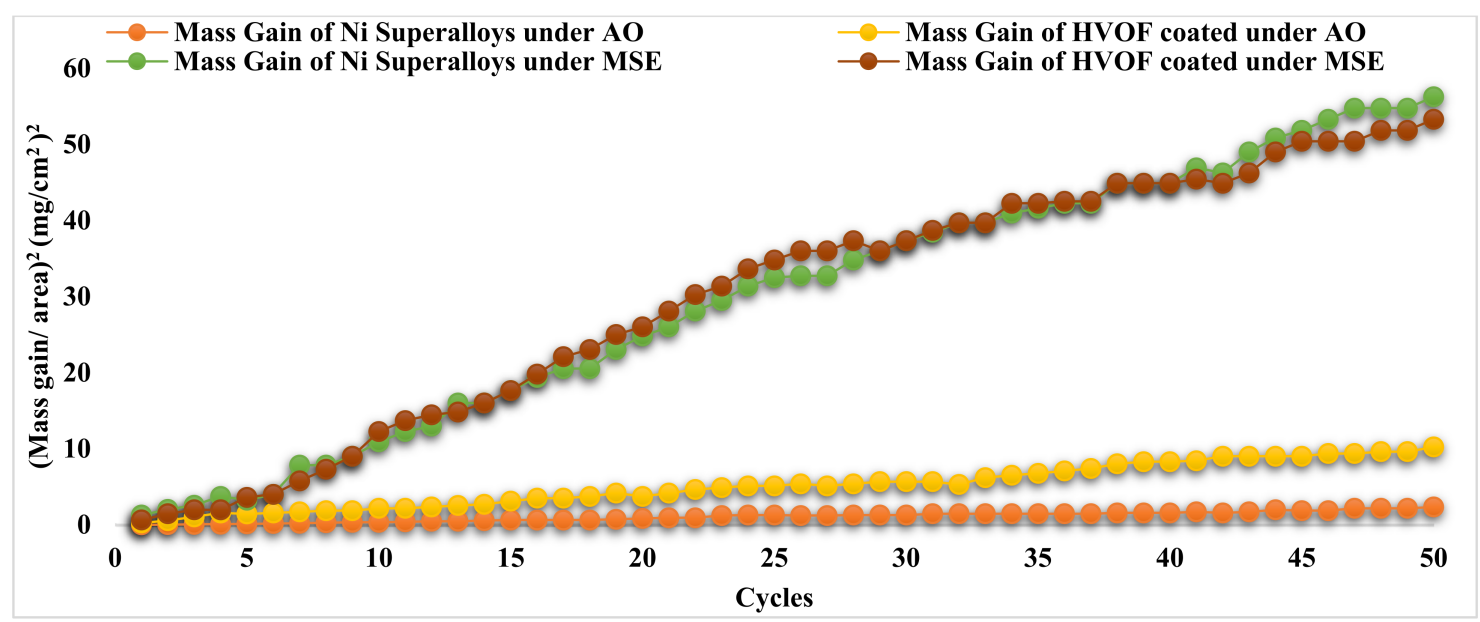

Figure 10. (Mass gain/area) ${ }^{2}$ vs. fifty corrosion cycles for Ni superalloys (undeposited and HVOF-deposited) under AO and MSE at $950^{\circ} \mathrm{C}$. 


\subsection{Discussion of HT Corrosion on APS and HVOF Depositions}

APS-deposited Ni superalloys revealed a high mass gain under the AO domain, which was ascribed to insufficient oxidation resistance as deposition decomposes into carbides when oxygen rejoins with $\mathrm{Cr}_{3} \mathrm{C}_{2}$ to produce $\mathrm{Cr}_{2} \mathrm{O}_{3}$ and releases $\mathrm{CO} / \mathrm{CO}_{2}$. This will severely spall the deposited layers along edges, ascribed to the $\mathrm{CO} / \mathrm{CO}_{2}$ pressure in deposition; moreover, thermal expansion differences exist between deposition and oxide formation. The generation of $\mathrm{Cr}_{7} \mathrm{C}_{3}$ and $\mathrm{Cr}_{23} \mathrm{C}_{6}$ carbide phases also observed when plasma sprayed $\mathrm{Cr}_{3} \mathrm{C}_{2} \mathrm{NiCr}$ coatings were subjected to $\mathrm{HT}\left(871^{\circ} \mathrm{C}\right)$. In the APS-deposited Ni superalloys, only major elements such as $\mathrm{Cr}$ and $\mathrm{Ni}$ elements were found, which formed salt reactions with $\mathrm{NiO}$ and $\mathrm{Cr}_{2} \mathrm{O}_{3}$ oxides during the $\mathrm{HC}$ kinetics in the MSE.

During the first cycle of the $\mathrm{HC}$ test, oxidation of the undeposited Ni superalloy formed $\mathrm{NiO}$ at $400{ }^{\circ} \mathrm{C}$; moreover, between 500 and $600{ }^{\circ} \mathrm{C}, \mathrm{Cr}_{2} \mathrm{O}_{3}$ was formed under the MSE domain with the solid salt coating. Below $950{ }^{\circ} \mathrm{C}$, the formation of non-shielding salt compound $\mathrm{NaNiO}_{2}$ and sulfate compound $\mathrm{NiSO}_{4}$, whose boiling point is $840{ }^{\circ} \mathrm{C}$ occurred [40]. At $900{ }^{\circ} \mathrm{C}, \mathrm{NaVO}_{3}$ has a molten-stage temperature of $610{ }^{\circ} \mathrm{C}$ in a liquid state and begins to attack the thin protecting oxide films $\left(\mathrm{NiO}\right.$ and $\left.\mathrm{Cr}_{2} \mathrm{O}_{3}\right)$ developed under salt accumulation [38]. They form the $\mathrm{Na}_{2} \mathrm{CrO}_{4}$ salt compound in the undeposited $\mathrm{Ni}$ superalloy under MSE, which evaporates in gas form at $900{ }^{\circ} \mathrm{C}$, leading to chromium reduction and hence the reduced HR resistance, as noted by [41]. The HC resistance of the undeposited metal was better than that of the APS-deposited Ni superalloys, and this was ascribed to the formation of $\mathrm{NiCr}_{2} \mathrm{O}_{4}$, which is less porous [33].

The formation of $\mathrm{NiO}, \mathrm{Cr}_{2} \mathrm{O}_{3}$ and $\mathrm{NiCr}_{2} \mathrm{O}_{4}$ oxides on the HVOF-deposited $\mathrm{Ni}$ superalloys was observed when exposed to the MSE domain. The high $\mathrm{Cr}$ presence in deposition delayed the hostile reactions of acid instability phase $\mathrm{HC}$ by developing well-built $\mathrm{Cr}_{2} \mathrm{O}_{3}$, which reduces the presence of $\mathrm{V}_{2} \mathrm{O}_{5}$ in MSE [33]. Improved oxidation resistance was seen in the undeposited rather than the HVOF-deposited $\mathrm{Ni}$ superalloys, as the oxide states $(\mathrm{NiO}$, $\mathrm{Ni}_{2} \mathrm{O}_{3}$, and $\mathrm{Cr}_{2} \mathrm{O}_{3}$ ) and high-level uniformity were established to act as a dispersion barrier, which regulates the downward distribution of $\mathrm{O}_{2}$ into the Ni superalloy's surface [25]. In the $\mathrm{AO}$ domain, the formed $\mathrm{Cr}_{2} \mathrm{O}_{3}$ and $\mathrm{NiCr}_{2} \mathrm{O}_{4}$ acted as diffusion barriers at the junction of the deposited surface under the $\mathrm{AO}$ domain to limit additional oxidation of the sublayers of the depositions. The growth of the $\mathrm{Cr}_{7} \mathrm{C}_{3}$ segment and unoccupied carbon in $\mathrm{HVOF}$ deposits was attributable to the breakdown of $\mathrm{Cr}_{3} \mathrm{C}_{2}$ [42]. The oxidation of $\mathrm{Cr}_{3} \mathrm{C}_{2}$ and $\mathrm{Cr}_{7} \mathrm{C}_{3}$ phases under the AO domain produced a mass gain in the HVOF-deposited $\mathrm{Ni}$ superalloy [39]. The low mass gain of the HVOF-deposited NI superalloy was due to the presence of the high quantity of $\mathrm{Cr}$ in the depositing powder's composition. The high quantity of $\mathrm{Cr}_{2} \mathrm{O}_{3}$ decreased the ion matter of $\mathrm{Na}_{2} \mathrm{SO}_{4}$ to a very minimal value, at which sulfidation occurs.

\section{Conclusions}

The $\mathrm{Cr}_{3} \mathrm{C}_{2} 25 \mathrm{NiC}_{\mathrm{r}}$ powder was coated successfully by the APS and HVOF techniques and showed a dense laminar structure with a bond/adhesion strength of more than $35 \mathrm{MPa}$ and $75 \mathrm{MPa}$, respectively. The generation of protecting oxides such as $\mathrm{NiO}$ and $\mathrm{Cr}_{2} \mathrm{O}_{3}$ is responsible for the $\mathrm{HC}$ resistance of the undeposited and APS-deposited base metals in both corrosive environments at $950^{\circ} \mathrm{C}$. HVOF developed well-bonded coatings that could withstand fifty corrosion cycles at $950^{\circ} \mathrm{C}$ without stripping off the base metal. The $\mathrm{K}_{\mathrm{P}}$ value from the (mass gain) ${ }^{2}$ curve of the APS deposits is very close to the Ni superalloy under both AO and MSE conditions. APS-deposited samples successfully safeguarded the base metal alloy $80 \mathrm{~A}$ against $\mathrm{HC}$ at $950{ }^{\circ} \mathrm{C}$ in MSE. The $\mathrm{K}_{\mathrm{P}}$ value of the deposited superalloy is very close to that of the undeposited Ni superalloys in the MSE condition. When exposed to MSE, the collective weight gain in the HVOF-coated base metal was $7.30 \mathrm{mg} / \mathrm{cm}^{2}$ which is less than that of the undeposited alloy $80 \mathrm{~A}$, of $7.46 \mathrm{mg} / \mathrm{cm}^{2}$.

Based on the present investigation, the HVOF process shown to provide better coating characteristics in terms of bond strength and HT corrosion resistance in both environments 
compared to the APS process. HVOF deposits can be considered to protect base metals under MSE $\left(\mathrm{Na}_{2} \mathrm{SO}_{4}+60 \% \mathrm{~V}_{2} \mathrm{O}_{5}\right)$.

In recent years, the high-velocity air fuel (HVAF) process has emerged as an alternative to the HVOF technique for the deposition of carbide and metallic coatings, as it has high velocity and temperature, a particle size of 5 to $38 \mu \mathrm{m}$ (15 to $45 \mu \mathrm{m}$ in HVOF) and, in air, it reduces the oxidation of particles. Studies on the HVAF process with $\mathrm{NiCrMoNb}$ and $\mathrm{Cr}_{3} \mathrm{C}_{2}-25 \mathrm{NiCr}$ coating powders are to be carried out under both AO and MSE conditions in the future. The $\mathrm{HC}$ resistance of $\mathrm{Cr}_{3} \mathrm{C}_{2}-50 \mathrm{NiCrMoNb}, \mathrm{Cr}_{3} \mathrm{C}_{2}-40 \mathrm{NiCr}, \mathrm{N}_{\mathrm{i}} \mathrm{CoCrAlH} \mathrm{H}_{\mathrm{f}} \mathrm{Si}$ and $\mathrm{N}_{\mathrm{i}} \mathrm{CoCrAlTaReY}$ coating powders can be evaluated at $950{ }^{\circ} \mathrm{C}$ to determine whether they can be used as alternatives for $\mathrm{Cr}_{3} \mathrm{C}_{2}-25 \mathrm{NiCr}$ powder under both $\mathrm{AO}$ and melted salt $\left(\mathrm{Na}_{2} \mathrm{SO}_{4}+0.6 \mathrm{~V}_{2} \mathrm{O}_{5}\right)$ environments.

Author Contributions: Conceptualization, I.A.A. and M.Y.; Data curation, M.Y.; Formal analysis, M.Y., R.A. and T.A.; Funding acquisition, I.A.A.; Investigation, M.Y., R.A. and T.A.; Methodology, I.A.A., M.Y., R.A. and T.A.; Project administration, I.A.A.; Resources, M.Y. and T.A.; Supervision, M.Y. and T.A.; Validation, M.Y. and T.A.; Visualization, R.A.; Writing-original draft, M.Y.; Writing-review \& editing, I.A.A., M.Y., R.A. and T.A. All authors have read and agreed to the published version of the manuscript.

Funding: The authors would like to thank the Saudi Basic Chemical Industries (SABIC) and the Deanship of Scientific Research at Umm Al-Qura University for supporting this work (grant code: 20-UQU-0070-DSR).

Institutional Review Board Statement: Not applicable.

Informed Consent Statement: Not applicable.

Data Availability Statement: The data underlying this article will be shared on reasonable request from the corresponding author.

Acknowledgments: The authors would like to thank the Deanship of Scientific Research at Umm Al-Qura University for supporting this work.

Conflicts of Interest: The authors have no conflict of interest. The funders had no role in the design of the study; in the collection, analyses, or interpretation of data; in the writing of the manuscript, or in the decision to publish the results.

\section{References}

1. Shirzadi, A.; Jackson, S. Structural Alloys for Power Plants; Elsevier: Amsterdam, The Netherlands, 2014; ISBN 9780857092380.

2. Asnavandi, M.; Kahram, M.; Rezaei, M.; Rezakhani, D. Fire-Side Corrosion: A Case Study of Failed Tubes of a Fossil Fuel Boiler. Int. J. Corros. 2017, 2017, 7367046. [CrossRef]

3. Kamal, S.; Jayaganthan, R.; Prakash, S. Evaluation of cyclic hot corrosion behaviour of detonation gun sprayed $\mathrm{Cr}_{3} \mathrm{C}_{2}-25 \% \mathrm{NiCr}$ coatings on nickel- and iron-based superalloys. Surf. Coat. Technol. 2009, 203, 1004-1013. [CrossRef]

4. Eliaz, N.; Shemesh, G.; Latanision, R.M. Hot corrosion in gas turbine components. Eng. Fail. Anal. 2002, 9, 31-43. [CrossRef]

5. Kumar, S.; Kumar, M.; Handa, A. Combating hot corrosion of boiler tubes-A study. Eng. Fail. Anal. 2018, 94, 379-395. [CrossRef]

6. Hu, H.; Nie, X.; Ma, Y. Corrosion and Surface Treatment of Magnesium Alloys. In Magnesium Alloys-Properties in Solid and Liquid States; InTech: London, UK, 2014.

7. Singh, A.; Sharma, V.; Mittal, S.; Pandey, G.; Mudgal, D.; Gupta, P. An overview of problems and solutions for components subjected to fireside of boilers. Int. J. Ind. Chem. 2018, 9, 1-15. [CrossRef]

8. Sivakumar, G.; Banerjee, S.; Raja, V.S.; Joshi, S.V. Hot corrosion behavior of plasma sprayed powder-solution precursor hybrid thermal barrier coatings. Surf. Coat. Technol. 2018, 349, 452-461. [CrossRef]

9. Cerullo, N.; Lomonaco, G. Corrosion issues in high temperature gas-cooled reactor (HTR) systems. In Nuclear Corrosion Science and Engineering; Elsevier: Amsterdam, The Netherlands, 2012; pp. 731-772. ISBN 9781845697655.

10. Wang, B.Q. Dependence of erosion-corrosion on carbide/metal matrix proportion for $\mathrm{HVOF} \mathrm{Cr}_{3} \mathrm{C}_{2}-\mathrm{NiCr}$ coatings. Surf. Eng. 1998, 14, 165-169. [CrossRef]

11. Shukla, V.N.; Trivedi, H.; Kumar, H.; Yadav, A. Surface Engineering Analysis of D-Gun Sprayed Cermet Coating in Aggressive Environment. Mater. Today Proc. 2017, 4, 10212-10215. [CrossRef]

12. Kutz, M. Handbook of Environmental Degradation of Materials; Elsevier Science: Amsterdam, The Netherlands, 2018; ISBN 9780323524728.

13. Garcia, E.; Lee, H.; Sampath, S. Phase and microstructure evolution in plasma sprayed $\mathrm{Yb}_{2} \mathrm{Si}_{2} \mathrm{O}_{7}$ coatings. J. Eur. Ceram. Soc. 2019, 39, 1477-1486. [CrossRef] 
14. Liu, X.; He, D.; Zhou, Z.; Wang, G.; Wang, Z.; Guo, X. Effect of post-heat treatment on the microstructure of micro-plasma sprayed hydroxyapatite coatings. Surf. Coat. Technol. 2019, 367, 225-230. [CrossRef]

15. Zhao, S.Q.; Dong, J.X.; Zhang, M.C.; Xie, X.S. Oxidation behaviors of new Ni-based superalloy at $950{ }^{\circ} \mathrm{C}$ and $1000{ }^{\circ} \mathrm{C}$. Rare Met. Mater. Eng. 2005, 34, 208-211.

16. Yin, B.; Liu, G.; Zhou, H.; Chen, J.; Yan, F. Sliding Wear Behavior of HVOF-sprayed $\mathrm{Cr}_{3} \mathrm{C}_{2}-\mathrm{NiCr} / \mathrm{CeO} 2$ Composite Coatings at Elevated Temperature up to $800^{\circ} \mathrm{C}$. Tribol. Lett. 2010, 37, 463-475. [CrossRef]

17. Hong, H.; Zhao, Y.; Jin, H. Proposed Partial Repowering of a Coal-Fired Power Plant Using Low-Grade Solar Thermal Energy. Int. J. Thermodyn. 2011, 14, 21-28.

18. Budinski, K.G. Engineering Materials: Properties and Selection; Prentice Hall: Englewood Cliffs, NJ, USA, 1996.

19. Ghosh, D.; Mitra, S.K. Plasma sprayed $\mathrm{Cr}_{3} \mathrm{C}_{2}-\mathrm{Ni}-\mathrm{Cr}$ coating for oxidation protection of 2.25Cr-1Mo steel. Surf. Eng. 2015, 31, 342-348. [CrossRef]

20. Choi, H.; Yoon, B.; Kim, H.; Lee, C. Isothermal oxidation of air plasma spray NiCrAlY bond coatings. Surf. Coat. Technol. 2002, 150, 297-308. [CrossRef]

21. Bhatia, R.; Singh, H.; Sidhu, B.S. Hot Corrosion Studies of HVOF-Sprayed Coating on T-91 Boiler Tube Steel at Different Operating Temperatures. J. Mater. Eng. Perform. 2014, 23, 493-505. [CrossRef]

22. Prakash, S.; Singh, S. Effects of $\mathrm{MgO}$ and $\mathrm{CaO}$ on hot corrosion of Fe base superalloy Superfer $800 \mathrm{H}^{\text {in }} \mathrm{Na}_{2} \mathrm{SO}_{4}-60 \% \mathrm{~V}_{2} \mathrm{O}_{5}$ environment. Br. Corros. J. 2002, 37, 56-62. [CrossRef]

23. Sharma, A.; Kant Verma, D.; Kumaran, S. Effect of post weld heat treatment on microstructure and mechanical properties of Hot Wire GTA welded joints of SA213 T91 steel. Mater. Today Proc. 2018, 5, 8049-8056. [CrossRef]

24. Somasundaram, B.; Kadoli, R.; Ramesh, M.R. Hot Corrosion Behaviour of HVOF Sprayed $\left(\mathrm{Cr}_{3} \mathrm{C}_{2}-35 \% \mathrm{NiCr}\right)+5 \% \mathrm{Si}$ Coatings in the Presence of $\mathrm{Na}_{2} \mathrm{SO}_{4}-60 \% \mathrm{~V}_{2} \mathrm{O}_{5}$ at $700{ }^{\circ} \mathrm{C}$. Trans. Indian Inst. Met. 2015, 68, 257-268. [CrossRef]

25. Bala, N.; Singh, H.; Prakash, S.; Karthikeyan, J. Investigations on the Behavior of HVOF and Cold Sprayed Ni-20Cr Coating on T22 Boiler Steel in Actual Boiler Environment. J. Therm. Spray Technol. 2012, 21, 144-158. [CrossRef]

26. Hong, S.; Wu, Y.; Li, G.; Wang, B.; Gao, W.; Ying, G. Microstructural characteristics of high-velocity oxygen-fuel (HVOF) sprayed nickel-based alloy coating. J. Alloys Compd. 2013, 581, 398-403. [CrossRef]

27. Paul, S.; Harvey, M.D.F. Corrosion Testing of Ni Alloy HVOF Coatings in High Temperature Environments for Biomass Applications. J. Therm. Spray Technol. 2013, 22, 316-327. [CrossRef]

28. Ramesh, M.R.; Prakash, S.; Nath, S.K.; Sapra, P.K.; Krishnamurthy, N. Evaluation of Thermocyclic Oxidation Behavior of HVOF-Sprayed NiCrFeSiB Coatings on Boiler Tube Steels. J. Therm. Spray Technol. 2011, 20, 992-1000. [CrossRef]

29. Houdková, Š.; Česánek, Z.; Smazalová, E.; Lukáč, F. The High-Temperature Wear and Oxidation Behavior of CrC-Based HVOF Coatings. J. Therm. Spray Technol. 2018, 27, 179-195. [CrossRef]

30. Yu, B.; Li, Y.; Nie, Y.; Mei, H. High temperature oxidation behavior of a novel cobalt-nickel-base superalloy. J. Alloys Compd. 2018, 765, 1148-1157. [CrossRef]

31. Kamal, S.; Jayaganthan, R.; Prakash, S. High temperature cyclic oxidation and hot corrosion behaviours of superalloys at $900{ }^{\circ} \mathrm{C}$. Bull. Mater. Sci. 2010, 33, 299-306. [CrossRef]

32. Kaur, M.; Singh, H.; Prakash, S. High-temperature behavior of a high-velocity oxy-fuel sprayed $\mathrm{Cr}_{3} \mathrm{C}_{2}-\mathrm{NiCr}_{\mathrm{C}}$ coating. Metall. Mater. Trans. A Phys. Metall. Mater. Sci. 2012, 43, 2979-2993. [CrossRef]

33. Sidhu, T.S.; Prakash, S.; Agrawal, R.D. Hot corrosion studies of HVOF sprayed $\mathrm{Cr}_{3} \mathrm{C}_{2}-\mathrm{NiCr}$ and Ni-20Cr coatings on nickel-based superalloy at $900{ }^{\circ}$ C. Surf. Coat. Technol. 2006, 201, 792-800. [CrossRef]

34. ASTM C633-13(2017). Standard Test Method for Adhesion or Cohesion Strength of Thermal Spray Coatings; ASTM International: West Conshohocken, PA, USA, 2017.

35. Yilbas, B.S.; Khalid, M.; Abdul-Aleem, B.J. Corrosion Behavior of HVOF Coated Sheets. J. Therm. Spray Technol. 2003, 12, 572-575. [CrossRef]

36. ASTM E384-17. Standard Test Method for Microindentation Hardness of Materials; ASTM International: West Conshohocken, PA, USA, 2017.

37. Hawthorne, H.; Arsenault, B.; Immarigeon, J.; Legoux, J.; Parameswaran, V. Comparison of slurry and dry erosion behaviour of some HVOF thermal sprayed coatings. Wear 1999, 225-229, 825-834. [CrossRef]

38. Yunus, M.; Alsoufi, M.S. Multi-output optimization of tribological characteristics control factors of thermally sprayed industrial ceramic coatings using hybrid Taguchi-grey relation analysis. Friction 2016, 4, 208-216. [CrossRef]

39. Fontana, M.G. High-Temperature Corrosion (Corrosion Engineering), 3rd ed.; Tata McGraw-Hill Book Company: New York, NY, USA, 1987.

40. Sreenivas, K.S.; Radhakrishnan, V.M. Oxidation and hot corrosion behaviour of Nimonic-75 superalloy. Indian J. Eng. Mater. Sci. 1998, 5, 295-301.

41. Fryburg, G.C.; Kohl, F.J.; Stearns, C.A.; Fielder, W.L. Chemical Reactions Involved in the Initiation of Hot Corrosion of IN-738. J. Electrochem. Soc. 1984, 131, 2985. [CrossRef]

42. Crawmer, D.C. Coating development for HVOF process using design of experiments. In Proceedings of the 13th International Thermal Spray Conference, Orlando, FL, USA, 25 May-5 June 1992. 